\title{
Different Training Programs of Mini-Basketball Players Have a Different Effect on Physical and Technical Preparation
}

\author{
Kęstutis Matulaitis ${ }^{1}$, Andris Rudzitis ${ }^{1}$, Mindaugas Barčaitis² ${ }^{2}$, Rasa Kreivyte் ${ }^{2}$, \\ Ramūnas Butautas ${ }^{2}$ \\ Latvian Academy of Sport Education', Riga, Latvia \\ Lithuanian Sports University², Kaunas, Lithuania
}

\begin{abstract}
Background. Basketball coaches need to find or create an effective training program while developing and training mini-basketball players. Only an effective and certified training program can help optimize the training process and bring success. So our aim of the analysis was also to determine and evaluate the effectivity of different training programs for mini-basketball players ( $8-9$ years old).

Methods. The study included $(n=38)$ mini-basketball (aged $8.5 \pm 0.27$ years) players. During the study, the subjects were split into three separate groups of training programs (universal, technical, integral). Groups were formed in random order, based on their place of residence. Mini-basketball players of different training programs were tested before and after the study, which lasted for 4 months ( 17 weeks) during the competitive period.

Results. The analysis of the results showed that the indicators increased the most after applying the Universal Training Program (UTP). After applying the UTP for 4 months, the indicators of speed increased by $1.9 \%$ and agility by $4.99 \%(p<.05)$, however, speed-strength increased by $4.64 \%$ and endurance by $-5.64 \%$ when applying the Technical Training Program (TTP). The most time in TTP was spent developing skills (30.7\%), but all of the indicators of technical skills increased, in UTP $20.3 \%$ of all the training time was spent on technical fitness. The indicators of dribbling (control dribble test) in the Universal Training Programme increased by $10.91 \%(p<.05)$, (20m basketball dribbling test) by $3.7 \%(\mathrm{p}<.05)$, shooting by $21.06 \%(p<.05)$.

Conclusions. The results of the study showed that the mini-basketball players participating in the study corresponded to a good level of preparation. The most effective program for mini- basketballs players - Universal Training Program, in which an equal amount of attention is given to integral, physical and technical fitness.
\end{abstract}

Keywords: mini-basketball, training program, development.

\section{INTRODUCTION}

$\mathrm{D}$ uring the initial stages of preparation (7 to 10 years of age), fundamental skills of movement and technique are in development (Malina, Bouchard, \& Bar-Or, 2004). While working with mini-basketball players, it is essential to understand the main peculiarities of their development and to plan and prepare separate individual cycles of athletic training programs according to it. The program should aid in planning, controlling and operating the process of training not only during the yearly training cycle, but also during the days of individual microcycles or training sessions (Butautas, 2002; Kreivyte, 2012; Matulaitis, 2013; Paulauskas, 2015; Rudzitis, 2003; Stonkus, 2003).

While developing a talented athlete who is aspiring for great athletic performance, it is important to structure a single-minded program 
and coherently implement it in practice (Ford et al., 2011). It is important to apply optimal training methods for talented athletes. Inaccurate training system does not allow the athletes to fully display their potential, whereas a consistent system of sports training can quicken the upturn of athletic performance (Balyi \& Williams, 2009; Malina et al., 2004). An important condition of effective sports training is the control of sports training, the estimation and evaluation of the players' physical development, physical fitness and changes in technical skills (Matulaitis, Skarbalius, Abrantes, Goncalves, \& Sampaio, 2019).

Different training programs are applied while training 8-9-year-old basketball players, but their effectivity for physical development is not justified. What training programs are the most effective for the physical development of 8-9-year-old basketball players?

The aim of analysis was to determine and evaluate the effectivity of different training programs for mini-basketball players (8-9 years old).

\section{METHODS}

Subjects. The $8-9(8.5 \pm 0.27)$ year old minibasketball players $(n=38)$ of Lithuania, Kaunas city, participated in the study (Table 1).

Research process and training programs. During the study, the subjects were split into three separate groups of training programs (universal, technical, integral). The groups were formed in random order, based on their place of residence. Mini-basketball players of different training programs were tested before and after the study, which lasted for 4 months (17 weeks) during the competitive period. The content of training was recorded during every training session. Without regularly applicable integral, technical and-physical types of training, two very significant types of training content were emphasized: the preparation of the players for the main part of training (warmup), and the time for recovery between physical exercise during training (Gamble, 2010). An intended time-limit was indicated at each type of preparation in every protocol of exercise recording and the time-limit (in minutes) and percentages were calculated after training. The content of applied types of training was recorded by the trainer, who would then document the intended time-limit in the protocol of recording.

The content of experimental training programs was documented throughout the study (Table 2, Figure 1). An equal amount of attention in Universal Training Program (UTP) was given to technical (20.3\%), integral (26.8\%), and physical (20.3\%) training; in Technical Training Program (TTP) to technical $-28.5 \%$ and integral $-30.7 \%$; in Integral Training Program (ITP) the most attention was given to integral training $-40.5 \%$.

Testing. The tests were initiated twice: at the start of the study and after it. Before and after the study, the subjects were being tested for two days in a row at the same time of the day (after lunch between 15.00 and 18.00). Before the testing, the subjects were informed about the testing and its sequence, as well as about the significance of the research. Ten minutes before the testing, the subjects performed the standard warm-up (similar to the one performed during the practice sessions) led by their coach. Testing for the subject groups was performed in a 2-day period. In the first testing we measured the anthropometric and $20 \mathrm{~m}$ running, Illinois agility, vertical jump with swings the arms backward, 6 min running test (around $90 \mathrm{~min}$ ). The second day was dedicated to the measurement of control dribble, $20 \mathrm{~m}$ basketball dribbling, shooting from close to the basket test of the subjects (around $90 \mathrm{~min})$.

Table 1. Subjects of different training programs (mean $\pm S D)$

\begin{tabular}{|l|c|c|c|}
\hline \multicolumn{1}{|c|}{ Programs } & $\begin{array}{c}\text { Universal Training } \\
\text { Program (UTP) }\end{array}$ & $\begin{array}{c}\text { Technical Training } \\
\text { Program (TTP) }\end{array}$ & $\begin{array}{c}\text { Integral Training } \\
\text { Program (ITP) }\end{array}$ \\
\hline Subjects $(n)$ & 12 & $8.66 \pm 0.27$ & $8.51 \pm 0.28$ \\
\hline Age (years) & $8.42 \pm 0.22$ & $33.2 \pm 6.8$ & $33.3 \pm 6$ \\
\hline Body mass (kg) & $31.6 \pm 5.5$ & $140.6 \pm 6.3$ & $138 \pm 6.3$ \\
\hline Height $(\mathrm{cm})$ & $135.2 \pm 7.2$ & & \\
\hline
\end{tabular}


Table 2. Regulatory part of training programs for mini-basketball players (8-9 years of age)

\begin{tabular}{|c|c|c|c|c|}
\hline \multicolumn{2}{|c|}{ Load indicators } & $\begin{array}{l}\text { Universal training } \\
\text { program (UTP) }\end{array}$ & $\begin{array}{l}\text { Technical training } \\
\text { programa (TTP) }\end{array}$ & $\begin{array}{l}\text { Integral training } \\
\text { program (ITP) }\end{array}$ \\
\hline \multicolumn{2}{|c|}{$\begin{array}{l}\text { Frequency of training (numbers of } \\
\text { time a week) }\end{array}$} & $2 \times 60+1 \times 90$ & $2 \times 75+1 \times 60$ & $2 \times 60+1 \times 90$ \\
\hline \multicolumn{2}{|c|}{ Numbers of weeks of training } & \multicolumn{3}{|c|}{17} \\
\hline \multicolumn{2}{|c|}{ Number of practices } & 39 & 39 & 40 \\
\hline \multicolumn{2}{|c|}{ Number of hours of training } & 55 & 56.75 & 54.25 \\
\hline \multirow{6}{*}{$\begin{array}{l}\text { Content of } \\
\text { training, } \\
\text { hours }(\%)\end{array}$} & Warm-up & $8.8(16 \%)$ & $9.08(16 \%)$ & $8.68(16 \%)$ \\
\hline & Recovery & $5.34(9.7 \%)$ & $5.39(9.5 \%)$ & $5.05(9.3 \%)$ \\
\hline & Integral fitness & $14.74(26.8 \%)$ & $16.17(28.5 \%)$ & $21.97(40.5 \%)$ \\
\hline & Physical fitness & $11.17(20.3 \%)$ & $4.31(7.6 \%)$ & $3.96(7.3 \%)$ \\
\hline & Technical fitness & $11.17(20.3 \%)$ & $17.42(30.7 \%)$ & $10.47(19.3)$ \\
\hline & Theoretical fitness & $3.8(6.9 \%)$ & $4.37(7.7 \%)$ & $4.12(7.6 \%)$ \\
\hline \multicolumn{2}{|c|}{ Number of games } & \multicolumn{3}{|c|}{9} \\
\hline \multicolumn{2}{|c|}{ Predominant microcycle } & \multicolumn{3}{|c|}{$1-1+1-1+1-2$} \\
\hline
\end{tabular}

Figure 1. Distribution of different types of preparation in different training programs

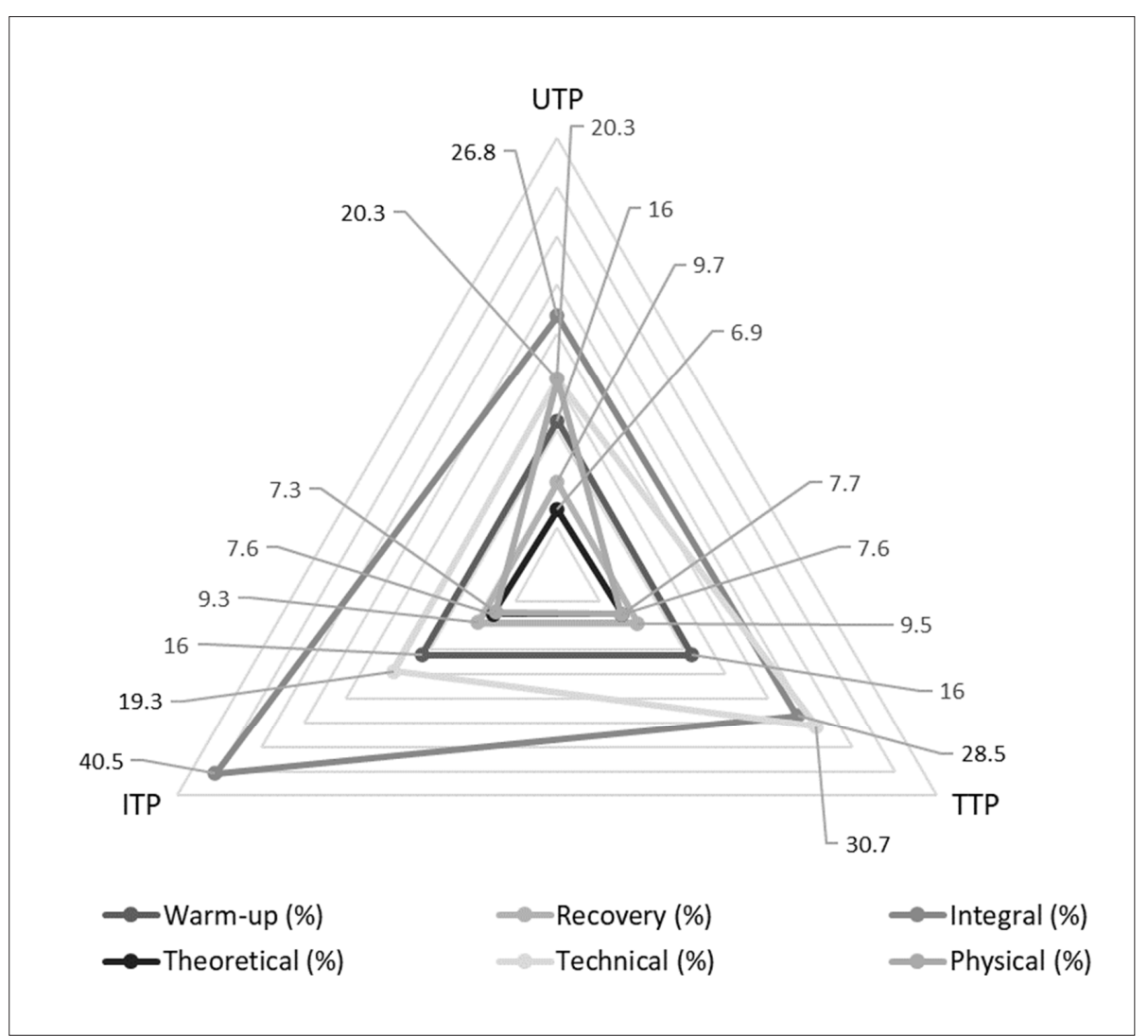




\section{Testing physical fitness}

$20 \mathrm{~m}$ running test (Parizkova \& Adamec, 1980). The test objective was to determine and assess the acceleration and locomotive speed of young basketball players. At the beginning and at the end of the $20 \mathrm{~m}$ distance, there were photoelectric cells connected to an electronic timer (Powertimer Testing System, NewTest, Tampere, Finland). The starting position was $70 \mathrm{~cm}$ from the first photocell. Two trials were performed with a recovery of approximately $3 \mathrm{~min}$ in between. The best running time was used for analysis.

Illinois agility test (Curetin, 1951). The test objective was to determine and assess general agility. Two optical sensors (at the start line and the finish of the distance) were connected with the electronic timer, electronic control and measurement panel, connecting cable (NewTest, Finland), and six landmarks. The starting position was $70 \mathrm{~cm}$ from the first photocell. Two trials were performed with a recovery of approximately $3 \mathrm{~min}$ in between. The best running time was used for analysis.

Vertical jump with swings the arms backward test (Sargent, 1921). The test objective was to determine and assess the power of extensor muscles of legs of basketball players, vertical jump. The tested player stood on a contact plate Kistler. They concentrated, squats until their knees formed a 135-degree angle (measured using the goniometer) and waving the hands tried to jump into the air as high as they could. The tested player attempted the three times with $60 \mathrm{~s}$ breaks between the attempts. The best attempt $(\mathrm{cm})$ was recorded.

6 min running test (Bolonchuk, 1971). The test objective was to determine and assess general stamina. Test was performed on a basketball court. Without any command the tested player began running towards the baseline, plants one foot on a baseline and runs back. They ran back and forth for $6 \mathrm{~min}$ and try to run as longer distance as possible. The information on the remaining time was communicated with one minute intervals whereas the last $10 \mathrm{~s}$ were calculated loudly. A command "stop" was given after a 6-min period and the tested player has to stop instantly. A stop place of each tested player was notified in a special protocol and the distance run throughout the period is calculated. One researcher was registering a distance run by $1-2$ players, whereas a test could be performed simultaneously by $8-10$ tested players. A distance (m) run by the player in 6 min time.

\section{Testing technical fitness}

Control dribble test (Johnson \& Nelson, 1986). The test objective was to measure ball-handling skills while moving. Six cones were set up in the free-throw lane of a basketball court to provide obstacles. On the signal "Ready, go" the performer started dribbling with the non-dominant hand from the non-dominant hand side of stand A to the nondominant hand side of stand B (left-handed dribble). Three timed trials are given. Recovery between trials was $5 \mathrm{~min}$. The best result was used for analysis.

$20 \mathrm{~m}$ basketball dribbling test (Matulaitis, 2013). The test objective was to establish and assess the speed of players while dribbling a ball. At the beginning and at the end of the $20 \mathrm{~m}$ distance, there were photo-electric cells connected to an electronic timer (Powertimer Testing System, NewTest, Tampere, Finland). The starting position was $70 \mathrm{~cm}$ from the first photocell. Two trials were performed with a recovery of approximately $3 \mathrm{~min}$ in between. The best running time was used for analysis.

Shooting from close to the basket test (Johnson $\&$ Nelson, 1986). The test objective was to determine and assess the players' shooting consistency from different positions of the basketball court, dribbling skills and agility of the players. Five positions were marked close to the basket (1, 2, 3, 4 and 5) from which the player had to shoot the ball. The positions $\mathrm{w}$ distanced at $2.74 \mathrm{~m}$ from the basket. The distance of positions 1 and 5 were measured from the perpendicular of the basket construction, whereas the distance of positions 2, 3 and $4-$ from the perpendicular of the middle of the basketball rim. Upon the signal the player shot the ball to the basket from the selected position, ran toward the basket, took the ball and dribbled it to the next position, from which they shot it again. The drill was repeated until the time allocated for the drill ended. The time allocated for the test was $60 \mathrm{~s}$. A player was awarded 2 points for a successful shot and 1 point was awarded for unsuccessful shot if the ball was shot correctly and the ball fell at the rim from the above. Test was attempted three times: the first was a pilot attempt, whereas the second and the third were recorded. The break between second and third attempts was 7-8 min. The best attempt was recorded for the analysis purposes. The points 
were not awarded in case of technical errors (e.g. dribbling the ball), when the shots were performed incorrectly, the shots were taken from the same position twice or when the line of the position was crossed. In such cases the shot had to be performed from the same position.

Statistical data analysis was performed using SPSS V.19 and Office Excel 2016 program. The calculations included the determination of the arithmetic average, standard deviation, the reliability of the differences between averages in accordance with the Student's criterion for independent samples (that the normality of the distribution was tested by applying Kolmogorov-Smirnov criterion). In the assessment of the reliability of the results, the difference was deemed to be statistically significance where $p<.05$ (the reliability of 95\%). In order to evaluate the reproducibility of the test results the intraclass correlation coefficient (Cohen, 1988) was calculated. The difference in the results of various tests and body composition indices between different training programs were evaluated with respect to the effect size (Hopkins, 2006). The effect size was assessed using the Hopkins (2002) scale $(<0.2$ trivial; $0.2-0.6$ - small; $0.6-1.2-$ average; $1.2-2.0$ large; $>2.0$ very large).

\section{RESULTS}

\section{Physical fitness}

Speed. Before the study, the indicators of speed (20 m running test) of mini-basketball players in all of the training programs were similar; UTP $4.21 \pm 0.26 \mathrm{~s}$, TTP $-4.12 \pm 0.21 \mathrm{~s}$, ITP $-4.10 \pm$ $0.37 \mathrm{~s}$. A conclusion was made after the study that the indicators of-speed of mini-basketball players improved the most in UTP $-1.9 \%$, ITP $-0.49 \%$, TTP $-0.24 \%$ (Figure 2).

Agility. Before the study, the indicators of agility (Illinois agility test) of youth basketball players were similar: UTP $-23.04 \pm 1.5 \mathrm{~s}$, TTP $22.46 \pm 1.21 \mathrm{~s}$, ITP $-21.55 \pm 2.08 \mathrm{~s}$. A conclusion was made after the study that the indicators of agility of youth basketball players improved the most in UTP $-4.99 \%(p<.05)$, TTP $-1.9 \%$, ITP $0.28 \%$ (Figure 3).

Speed strength. Before the study, the indicators of vertical jump with wings the arms backward of mini-basketball players were similar - UTP $-26.31 \pm 4.39 \mathrm{~cm}$, TTP $-27.81 \pm$ $3.11 \mathrm{~cm}$, ITP $-24.55 \pm 5.39 \mathrm{~cm}$. After four months, it was determined that the indicators of jumping ability improved the most in TTP $-4.64 \%$, UTP $0.22 \%$, ITP $-8.55 \%$ (Figure 4 ).

Endurance. Before the study, the indicators of endurance (6-minute running test) of minibasketball players were similar in all of the training programs - UTP $-784 \pm 104.83 \mathrm{~m}$, TTP $703.62 \pm 101.3 \mathrm{~m}$, ITP $-817.38 \pm 110.14 \mathrm{~m}$. After the study, it was determined that the indicators of endurance improved the most in TTP $-5.64 \%$, indicators fell in UTP $-2.93 \%$ and ITP $-0.36 \%$ (Figure 5).
Figure 2. Indicators of $20 \mathrm{~m}$ sprint test (s) of mini-basketball players aged 8-9 years
Notes. $\#<0.2-$ trivial, \#\# 0.2-0.6 - small ES comparing the indicators of mini-basketball players before and after the study.
Before After

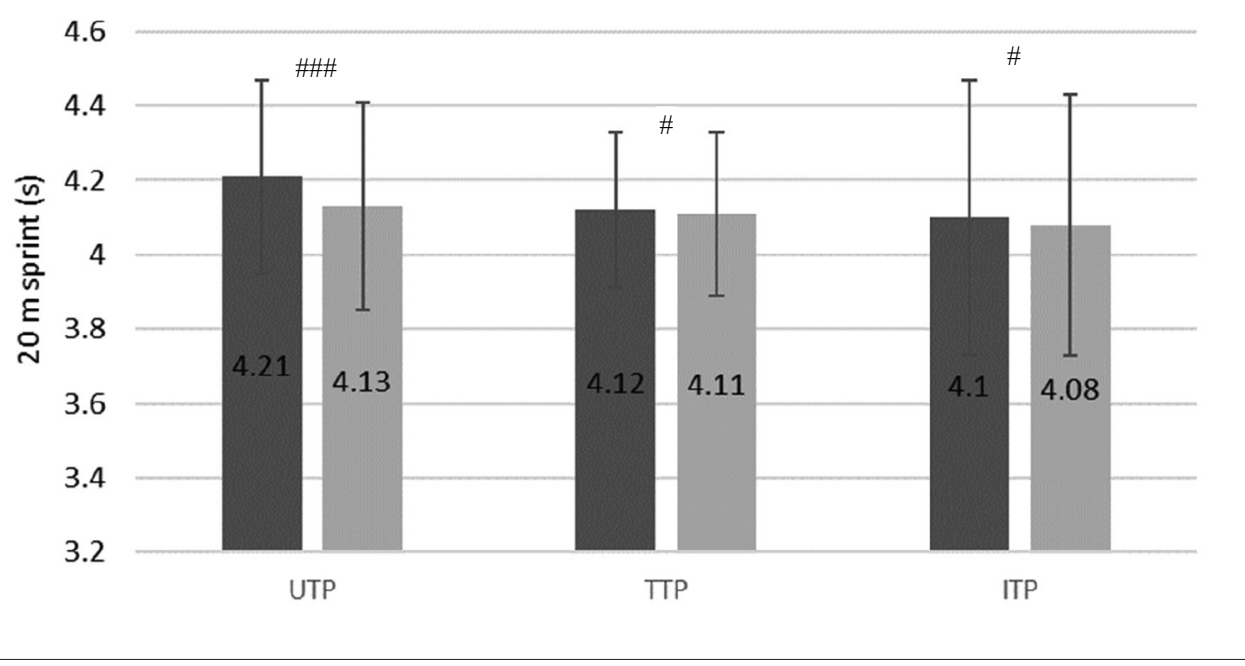


Figure 3. Indicators of Illinois agility test (s) of mini-basketball players aged 8-9 years

Notes. ${ }^{*} p<.05-$ statistically significant difference, $\#<0.2$ - trivial, \#\# 0.2-0.6 - small, \#\#\# 0.60-1.19 - average ES comparing the indicators of mini-basketball players before and after the study.

Figure 4. Indicators of vertical jump swinging the arms backward (cm) of mini-basketball players aged 8-9 years

Notes. \# $<0.2$ - trivial, \#\# 0.2-0.6 - small ES comparing the indicators of mini-basketball players before and after the study.

Figure 5. Indicators of 6 min running test $(\mathrm{m})$ of mini-basketball players aged 8-9 years

Notes. $\#<0.2$ - trivial, \#\# 0.2-0.6 - small ES comparing the indicators of mini-basketball players before and after the study.
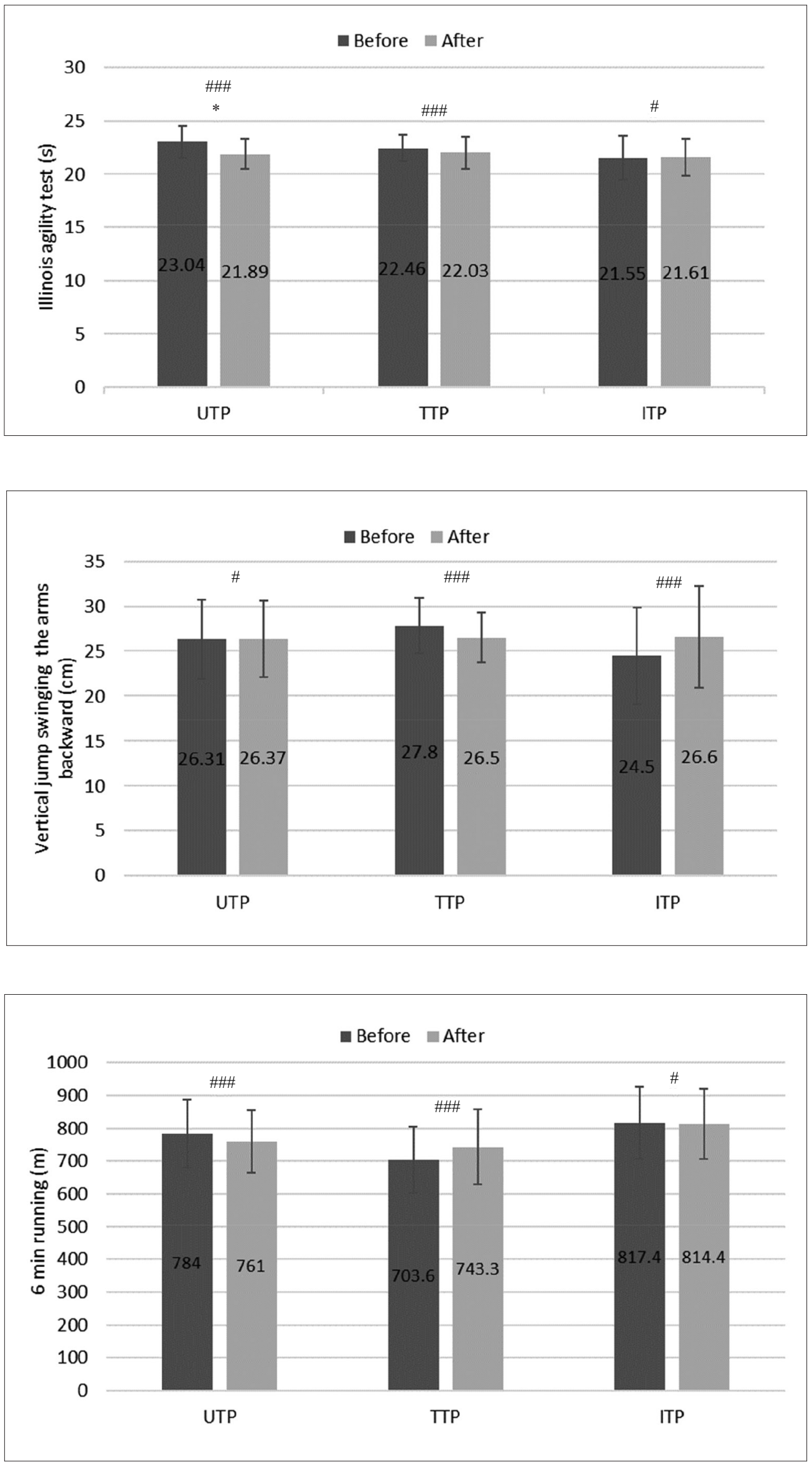


\section{Technical fitness}

Dribble. Before the study, the indicators of dribbling (control dribble test) of mini-basketball players were similar: UTP $-12.01 \pm 1.60 \mathrm{~s}$, TTP $11.62 \pm 1.09 \mathrm{~s}$, ITP $-11.47 \pm 2.03 \mathrm{~s}$. After the study, it was determined that the indicators of the test of changing direction when dribbling improved the most in UTP $-10.91 \%(p<.05)$, TTP $-3.79 \%(p<$ .05 ), ITP $-3.92 \%$ (Figure 6 ).

The indicators of ball handling $(20 \mathrm{~m}$ dribbling test) were similar in all training programs: UTP $4.87 \pm 0.54 \mathrm{~s}$, TTP $-4.85 \pm 0.45 \mathrm{~s}$, ITP $-4.81 \pm$ $0.81 \mathrm{~s}$. After the study, it was determined that the indicators of $20 \mathrm{~m}$ dribbling test of youth basketball players improved the most in UTP $-3.7 \%(p<.05)$, TTP $-1.03 \%$, ITP $-3.33 \%$.

Shooting. Before the study, the indicators of jump-shots (close-range shot test) of youth basketball players were similar - UTP $-13.42 \pm$ 3.87 pts, TTP $-14.77 \pm 5,15$ pts, ITP $-13.77 \pm$ 5.70 pts. After the study, it was determined that the indicators of close-range shots of youth basketball players improved the most in UTP $-21.06 \%$ $(p<.05)$ and ITP $-8.69 \%$ training programs. The indicators variated the least in TTP $-7.69 \%$ (Figure 8).
Figure 6. Indicators of control dribble test (s) of minibasketball players aged $8-9$ years

Notes. $* p<.05-$ statistically significant difference, \#\# 0.2-0.6 - small, \#\#\# 0.61.2 - average ES comparing the indicators of minibasketball players before and after the study.

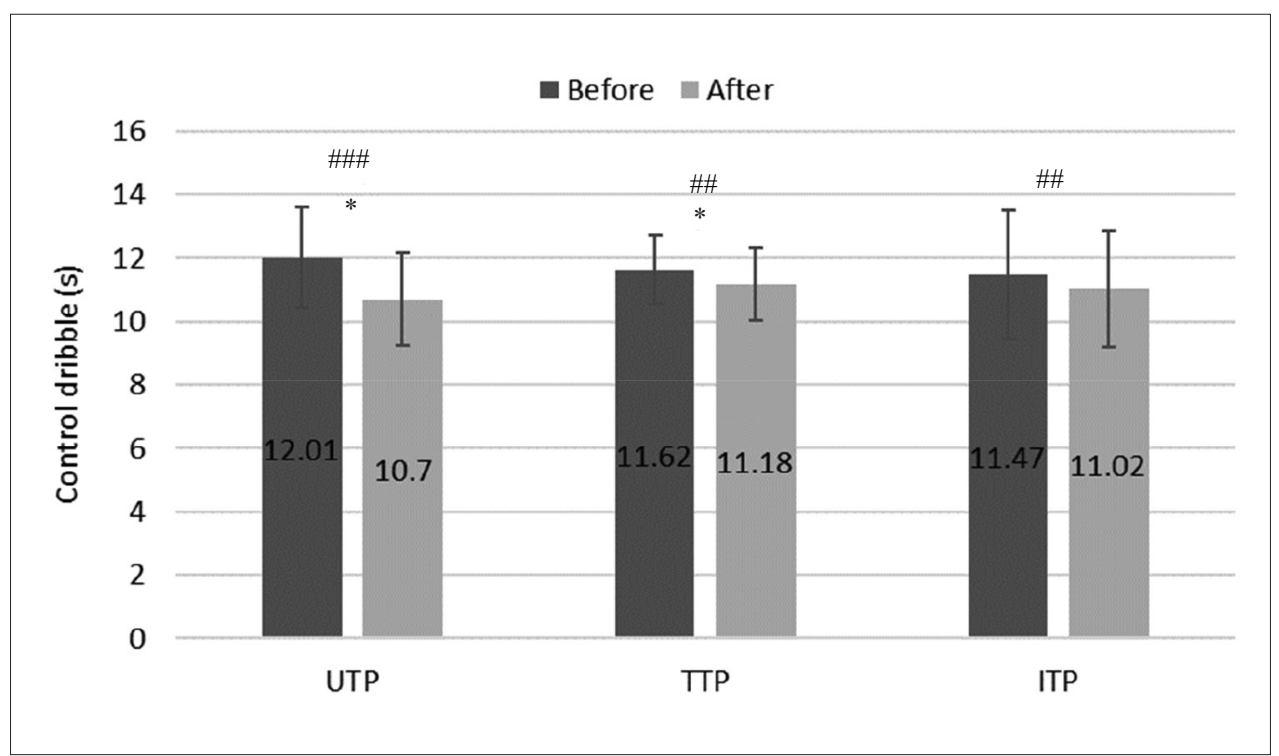

Figure 7. Indicators of $20 \mathrm{~m}$ sprint with dribbling test (s) of mini-basketball players aged 8-9 years

Notes. $* p<.05-$ statistically significant difference, \# $<0.2$ - trivial, \#\# 0.2-0.6 small ES comparing the indicators of mini-basketball players before and after the study.

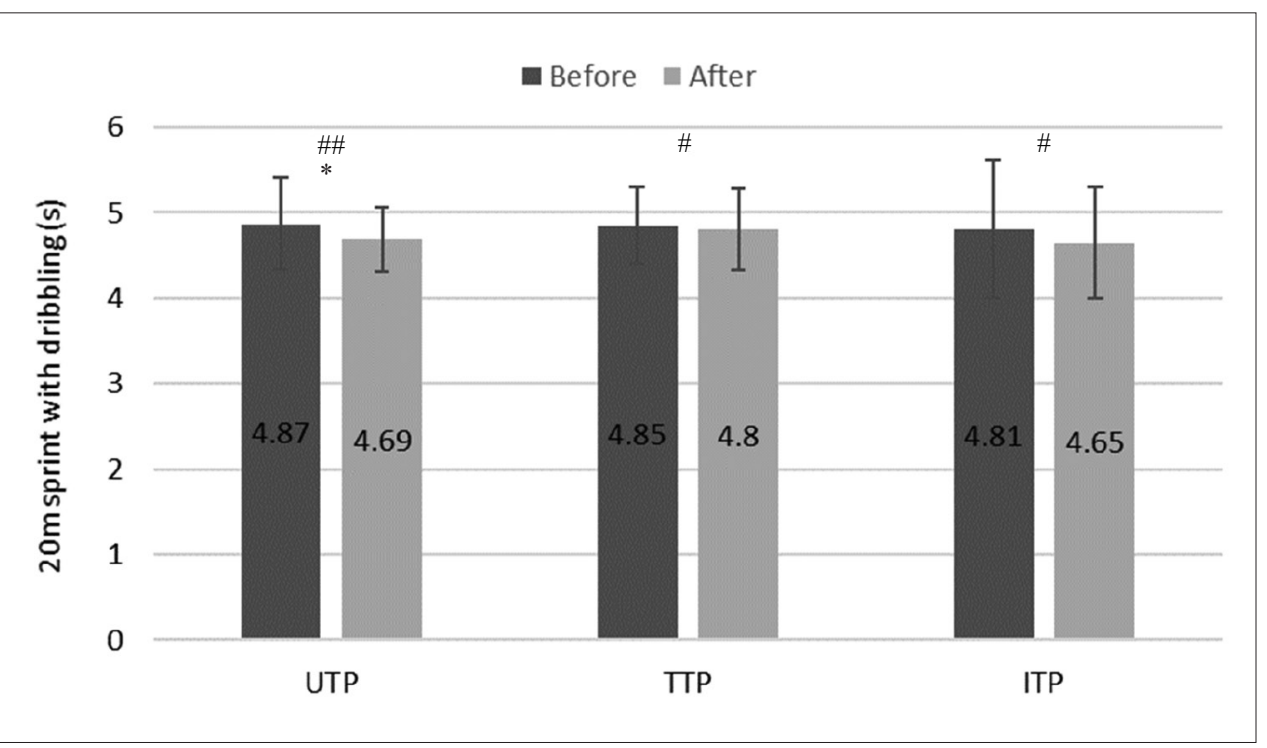


Figure 8. Indicators of shooting from close to the basket test (pts) minibasketball players aged 8-9 years
Notes. ${ }^{*} p<.05-$ statistically significant difference, \#\# 0.2-0.6 - small; \#\#\# 0.6-1.2 - average ES comparing the indicators of mini-basketball players before and after the study.

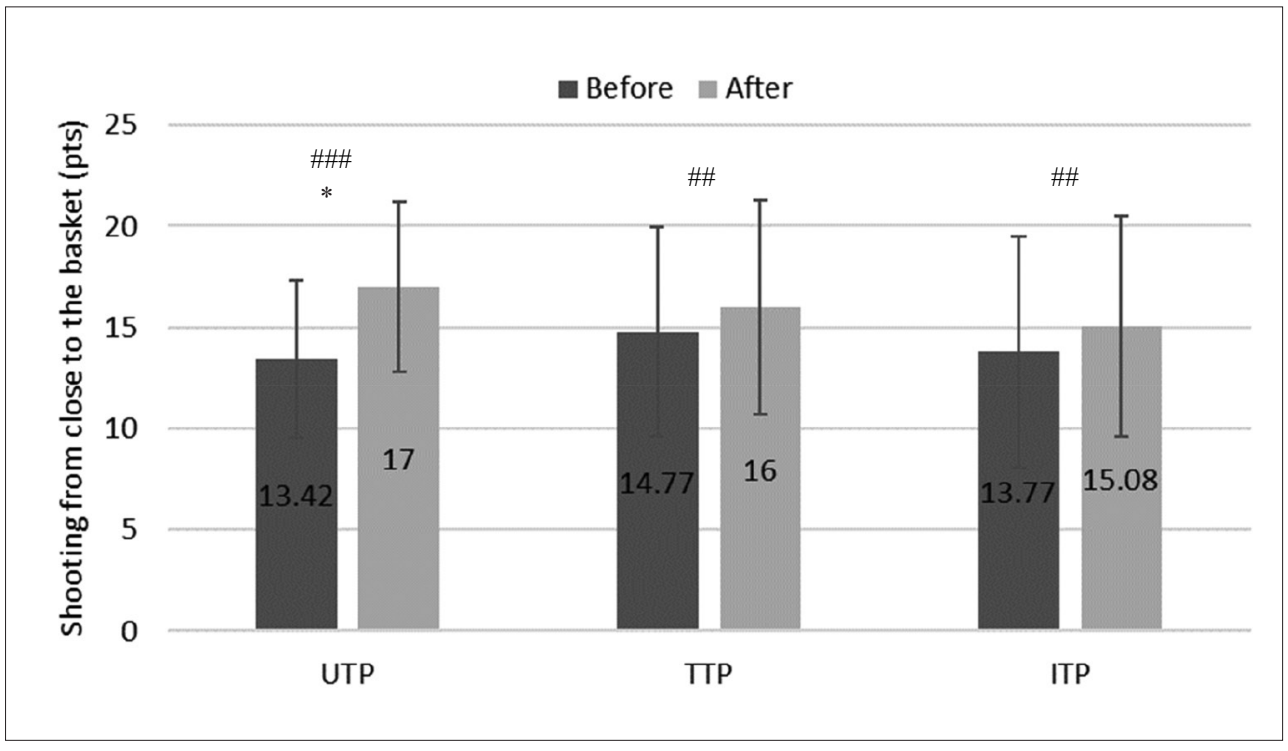

\section{DISCUSSION}

Peculiarities of physical fitness. The physical fitness of basketball players and the change of it can be objectively determined and evaluated by knowing and understanding the criteria of the main components of physical fitness: speed, strength, endurance and agility (Klimantowicz, 1999). We determined that after four months, the indicators of physical fitness for mini-basketball players improved the most by using the Universal Training Programme and improved the least by using the Integral Training Program.

A 20-meter running test was used to determine and evaluate speed (Drinkwater, Hopkins, McKenna, Hunt, \& Pyne, 2007; Hopker, Coleman, Wiles, \& Galbraith, 2009). It was determined that the indicators of examined basketball players and those of other scientists (Matulaitis, 2013; A. Viru, Laaneots, Karelson, Smirnova, \& M. Viru, 1998) are similar. It was determined that agility improved the most by using the Universal Training Programme.

Individual growth (Malina et al., 2004) and the content of the training programs (Trninic, Dizdar \& Luksic, 2002) we have applied might have had an impact on the change of the quickness and agility indicators of children. According to scientists (Kollias, Hatzitaki, Papaiakovou, \& Giatsis, 2001; Tomioka, Owings, \& Grabiner, 2001), agility (speed strength) is an integral ability of movement that depends on other abilities - strength, speed and coordination. While studying the indicators of the high jump with arms up test, we determined that it improved the most in Integral Training Program. By comparing the high jump with arms up test indicators of the basketball players we studied and those of other authors (Drinkwater et al., 2007; Matulaitis, 2013), we discovered that youth basketball players in this study corresponded to a good level of preparation.

Peculiarities of technical fitness. The technical preparation tests (Johnson \& Nelson, 1986; Ljach, 2007) show the peculiarities of different technical actions of basketball players by which we can determine and evaluate the technical preparation level of basketball players (Apostolidis, Nassis, Bolatoglou, \& Geladas, 2004). The exercising of technical skills is mostly related to the skills of movement (Karpowicz, 2006). We ascertained that after four months, the indicators of technical preparation for youth basketball players improved the most by using the Universal Training Programme $(p<.05)$. It was determined that the indicators of changing-direction-whendribbling-test improved the most by using UTP. The indicators of dribbling-the-ball-for-20-meters test improved the most by using UTP and ITP. While evaluating the indicators of our tests of changing-direction-when-dribbling and dribblingthe-ball-for-20-meters and those of other scientists, it was determined that the exploratory basketball players in this study corresponded to a good level of preparation. (Matulaitis et al., 2019). The main aim of all the shooting tests is to determine 
the precision of the shooting ability (Matulaitis, 2013). It was determined that the indicators of all the shooting tests allow determining the technical preparation level of the players (Pojskic, Šeparovic, \& Užičanin, 2011). By analysing the indicators of close-range shooting tests, it was discovered that at the start of the study, the indicators were worse than those of peers, but the indicators at the end of the study corresponded to a good level of preparation (Matulaitis et al., 2019).

\section{CONCLUSIONS}

It was determined that the level of technical and physical preparation of mini-basketball players participating in the study improved and corresponded to a good level of preparation. Different training programs had a different impact on physical and technical fitness. We ascertained that the indicators of technical and athletic preparation of mini-basketball players mostly increased during the four months of using the Universal Training Programme in which three types of preparation prevailed: integral fitness $-26.8 \%$ physical fitness $20.3 \%$, technical fitness $-20.3 \%$.

Acknowledgements. The authors thank the European Social Fund Project No.8.2.2.0/18/I/006 "Strengthening of the Academic Staff of the Latvian Academy of Sport Education in the Areas of Strategic Specialization".

Conflict of Interest Statement. The authors declare that the research was conducted in the absence of any commercial or financial relationships that could be construed as a potential conflict of interest.

\section{REFERENCES}

Apostolidis, N., Nassis, G. P., Bolatoglou, T., \& Geladas, N. D. (2004). Physiological and technical characteristics of elite young basketball players. The Journal of Sports Medicine and Physical Fitness, 4(2), 157-163.

Balyi, I., \& Williams, C. A. (2009). Coaching the young developing performer. Leeds: Coachwise UK.

Bolonchuk, W. W. (1971). A Critical Analysis of the AAHPER Youth Fitness Test. USA: Eric Clearinghouse.

Butautas, R. (2002). Vienalaikio poveikio metodo veiksmingumas, rengiant jaunuosius krepšininkus (Daktaro disertacija). Kaunas: LKKA.

Cohen, J. (1988). Statistical power analysis for the behavioural sciences. Hillsdale, NJ: Lawrence Erlbaum Associates.

Curetin, T. K. (1951). Physical Fitness of Champion Athletes. Urbana, IL: of Illinois Press.

Drinkwater, E. J., Hopkins, W. G., McKenna, M. J., Hunt, P. H., \& Pyne, D. B. (2007). Modelling age and secular differences in fitness between basketball players. Journal of Sports Sciences, 25(8), 869-878. https://doi.org/10.1080/02640410600907870

Ford, P., De Ste Croix, M., Lloyd, R., Meyers, R., Moosavi, M., Oliver, J., ... Williams, C. (2011). The Longterm athlete development model: Physiological evidence and application. Journal of Sports Sciences, 29(4), 389402. https://doi.org/10.1080/02640414.2010.536849

Gamble, P. (2010). Strength and conditioning for team sports. Oxon: Routledge.

Hopker, J. G., Coleman, D. A., Wiles, J. D., \& Galbraith, A. (2009). Familiarisation and reliability of sprint test indices during laboratory and field assessment. Journal of Sports Science and Medicine, 8(4), 528-532.
Hopkins, W. (2002). Probabilities of clinical or practical significance. Sport Science, 6. Retrieved from http:// sportsci.org/jour/0201/Statistical_vs_clinical.ppt

Hopkins, W. G. (2006). Spreadsheets for analysis of controlled trials, with adjustment for a subject characteristic. Sport Science. Retrieved from http:// sportsci.org/resource/stats/xPostOnlyCrossover.xls.

Johnson, B., \& Nelson, J. (1986). Practical measurements for evaluation in physical education. USA: Burgess Publishing.

Karpowicz, K. (2006). Interrelation of selected factors determining the effectiveness of training in young basketball players. Human Movement, 7(2), 130-146.

Klimantowicz, W. (1999). Koszykowka. Warszawa: Centralny oszrodek sportu.

Kollias, I., Hatzitaki, V., Papaiakovou, G., \& Giatsis, G. (2001). Using principal components analysis to identify individual differences in vertical jump performance. Research Quarterly for Exercise and Sport, 72(1), 6267. https://doi.org/10.1080/02701367.2001.10608933

Kreivytè, R. (2012). Skirtingu mokymo(si) metodiku bei pagalbiniu priemoniu taikymo poveikis baudos metimu tikslumui (Daktaro disertacija). Kaunas: LKKA.

Ljach, W. (2007). Koszykowka. Krakow: University School of Physical Education.

Malina, R. M., Bouchard, C., \& Bar-Or, O. (2004). Growth, maturation, and physical activity. Champaign, IL: HumanKinetics.

Matulaitis, K. (2013). Sabonio krepšinio centro jaunujų krepšininku treniravimas(is) (Daktaro disertacija). Kaunas: LSU. 
Matulaitis, K., Skarbalius, A., Abrantes, C. Gonçalves, B., \& Sampaio, J. (2019). Fitness, technical, and kinanthropometrical profile of youth Lithuanian basketball players aged 7-17 years old. Frontiers in Psychology, 10(1677). https://doi.org/10.3389/ fpsyg.2019.01677

Parizkova, J., \& Adamec, A. (1980). Longitudinal study of anthropometric, skinfold, work, and motor characteristics of boys and girls, three to six years of age. American Journal of Physical Anthropology, 52(3), 387-396. https://doi.org/10.1002/ajpa.1330520310

Paulauskas, R. (2015). Krepšininku rengimas. Vilnius: Lietuvos edukologijos universiteto leidykla.

Pojskic, H., Šeparovic V., \& Užičanin, E. (2011). Reliability and factorial validity of basketball shooting accuracy tests. Sport SPA, 8(1), 25-32.

Rudzitis, A. (2003). Jauno Basketbolistu Treninš. Riga: Latvijas Basketbala Savieniba, Latvijas Sporta Pedagogijas Akademija.
Sargent, D. A. (1921). The physical test of a man. American Physical Education Review, 26(1), 188-194. https://doi.org/10.1080/23267224.1921.10650486

Stonkus, S. (2003). Krepšinis. Istorija. Teorija. Didaktika. Kaunas: LKKA.

Tomioka, M., Owings, T. M., \& Grabiner, M. D. (2001). Lower extremity strength and coordination are independent contributors to maximum vertical jump height. Journal of Applied Biomechanics, 17(3), 181187. https://doi.org/10.1123/jab.17.3.181

Trninic, S., Dizdar, D., \& Luksic, E. (2002). Differences between winning and defeated top quality basketball teams in final of European club championship. Collegium Antropologicum, 2(26), 521-531.

Viru, A., Laaneots, L., Karelson, K., Smirnova, T., \& Viru, M. (1998). Exercise-induced hormonal responses in girls at different stages of sexual maturation. European Journal of Applied Physiology, 77(5), 401-408. https:// doi.org/10.1007/s004210050351 